(C) Group of authors, 2017

UDC 616.12-008.74-009.54

DOI - https://doi.org/10.14300/mnnc.2017.12071

ISSN -2073-8137

\title{
A CASE OF FAMILIAL THROMBOPHILIA IN THE PATIENT WITH COMPLICATED PERIPARTUM CARDIOMYOPATHY
}

\author{
Yagoda A. V., Gladkikh N. N., Znamenskaya I. A., Dereva M. V., Yagoda S. A.
}

Stavropol State Medical University, Russian Federation

САУЧАЙ НАСАЕАСТВЕННОЙ ТРОМБОФИАИИ У БОАЬНОЙ
С ОСАОЖНЕННОЙ ПЕРИПАРТААЬНОЙ КАРАИОМИОПАТИЕЙ

\author{
А. В. Ягола, Н. Н. Глалких, И. А. Знаменская, М. В. Аерева, С. А. Ягола \\ Ставропольский госуАарственный меАицинский университет, Российская ФеАерация
}

\begin{abstract}
Peripartum cardiomyopathy is a thrombophilia-associated disease, which manifests with severe heart failure and reduced left ventricular ejection fraction in patients without pre-existing cardiac pathology, usually 1 month before or after the delivery. Clinical observations suggest possible role of underlying congenital thrombophilia in the development of thromboembolism and formation of severe heart systolic dysfunction in patients with peripartum cardiomyopathy. We presented a clinical case of multiple biventricular thrombi in 28-year-old primigravida with peripartum cardiomyopathy and genetic traits of hereditary thrombophilia, which resulted in the recovery of heart contractile function. In conclusion, we discussed common genetic polymorphisms to investigate the link between the hereditary thrombophilia and peripartum cardiomyopathy.
\end{abstract}

Keywords: pregnancy, thrombophilia, cardiomyopathies, embolism and thromboses

Перипартальная кардиомиопатия представляет собой заболевание, ассоциированное с тромбофилией, манифестирующее выраженной сердечной недостаточностью и снижением фракции выброса левого желудочка у пациентов без предшествующей кардиальной патологии, обычно в пределах одного месяца до или после родов. Представлено клиническое наблюдение множественных бивентрикулярных тромбов у 28-летней первородящей женщины с перипартальной кардиомиопатией и признаками наследственной тромбофилии, с последующим восстановлением сократительной функции сердца. Представлен анализ генетических полиморфизмов у данной пациентки и обсуждены возможные связи между наследственной тромбофилией и перипартальной кардиомиопатией.

Ключевые слова: беременность, тромбофилия, кардиомиопатия, эмболия и тромбозы

linical significance of specific genetic defects in the hemostatic system and some forms of thrombophilia is not well understood, although a hereditary component has been identified in many thrombophilias. The association between genetic factors and thrombophilic states during pregnancy, childbirth, and in the postpartum period is an active field of research in coagulation disorders. Prothrombotic polymorphisms are common in women with arterial and venous thrombosis, infertility, fetal loss, fetoplacental insufficiency, growth retardation, preeclampsia, coronary atherosclerosis, ischemic stroke, myocardial infarction, and hypertension [4, 11].

Peripartum cardiomyopathy (PPCM), also known as postpartum cardiomyopathy, dilated cardiomyopathy of pregnant women, peripartum disease, and Meadows cardiomyopathy, is a thrombophilia-associated disease, which is not well represented in the field. PPCM occurs on average in 1 per 3000 to 4000 pregnancies, and manifests with severe heart failure in cases without pre-existing heart disease or reduced left ventricular (LV) ejection fraction during the third trimester or in the first 5 to 6 months after delivery. PPCM is one of the leading causes of pregnancy-associated morbidity and mortality [3, 8].

Etiology and pathogenesis of PPCM are unclear: some correlations with myocarditis, abnormal immune response to pregnancy, infectious (viral), nutritional and hormonal factors were found in several studies [1, 6]. Meanwhile, the clinical course of PPCM episodes directly or indirectly indicates its possible role in the development of hypercoagulable states. Certain pregnancy complications, which bear thrombophilic components (pre-eclampsia, eclampsia, gestational hypertension, spontaneous preterm birth, HELP syndrome), often precede PPCM. From the other side, thrombotic complications such as disseminated intravascular clotting (DIC), pulmonary embolism (PE), and intracardiac thrombi are presumably associated with a high procoagulant activity of the pregnancy itself (an increase of factors VII, VIII, X, fibrinogen and von Willebrand factor), as well as with the postpartum period.

Hereditary factors play a significant role in the development of the disease [2]. PPCM genetic traits, such as association of genome to locus chromosome 12p11.22, the presence of nucleotide polymorphism rs258415, and gene mutations $\mathrm{MYH7}$ and $\mathrm{MYH6}$ [5], presumably are not related to defect characteristics seen in congenital thrombophilias (such as factor $\mathrm{V}$ Leiden mutation, prothrombin G20210A, etc.). Our literature search did not reveal evidential data on the genetic relationship between the PPCM and hemostasis abnormalities, such as congenital thrombophilia, thromboembolisms, intra- and extracardiac thromboses at peripartum cardiomyopathy [7, 10]. However, our clinical observations provided below suggest 
that congenital thrombophilia in the PPCM patients may be the one of the causing factors for thromboembolism and formation of a severe heart systolic dysfunction.

Case report. A 28-year old Caucasian female with a family history of thrombophilia, whose mother and aunt died of pulmonary thromboembolism between the ages of 40 and 50, was admitted to a cardiac intensive care unit (ICU) complaining of a productive cough with brown sputum, shortness of breath, epigastric pain and bilateral leg edema. Eight days prior to admission, the patient underwent a cesarean section due to weakness of uterine contractions, giving birth to a healthy female infant. Onset of clinical symptoms occurred on the $3^{\text {rd }}$ day after the delivery.

Physical examination revealed acrocyanosis, swelling of lower extremities, pulse of 110, dullness of heart sounds, short systolic murmur over the apex and in the second parasternal intercostal space. Laboratory parameters were as follows: hemoglobin $11.2 \mathrm{~g} / \mathrm{dL}$, RBC $4.0 \mathrm{M} / \mu \mathrm{L}$, platelets $432 \mathrm{~K} / \mu \mathrm{L}$, elevated C-reactive protein $(186.6 \mathrm{mg} / \mathrm{mL})$ and $\mathrm{D}$-dimer $(2.7 \mu \mathrm{g} / \mathrm{mL})$, prolonged ac- tivated recalcification time (>180 sec), activated partial thromboplastin time (>180 sec), XIla-dependent fibrinolysis test was $15 \mathrm{~min}$, indicating decreased fibrinolytic activity (reference value 5-12 min). Total antibodies (IgM, $\lg \mathrm{G}, \lg \mathrm{A}$ ) to cardiolipin were in the normal range. Urinalysis revealed no abnormalities.

Echocardiography showed diffuse LV hypokinesis, and four mobile biventricular thrombi: in the apex $(1.5 \times 0.8 \mathrm{~cm})$ and anterolateral segment $(0.8 \times 0.9 \mathrm{~cm})$ of $\mathrm{LV}$; near the moderator band area $(1.0 \times 1.0 \mathrm{~cm})$ and in the middle portion of the septum $(1.0 \times 1.3 \mathrm{~cm})$ of right ventricle (Fig. 1). Doppler analysis identified mild pulmonary arterial hypertension with estimated pulmonary artery pressure of $40 \mathrm{~mm} \mathrm{Hg}$, and decreased LV ejection fraction of $34 \%$ (Teichholz). EKG revealed sinus arrhythmia from 140 to 65 bpm, right bundle-branch block, left anterior fascicular block, and LV hypertrophy. The patient was treated with aspirin, enoxaparin, clopidogrel, exogenous phosphocreatine, ivabradine, torasemide, spironolactone, perindopril, omeprazole, amoxicillin/clavulanate.

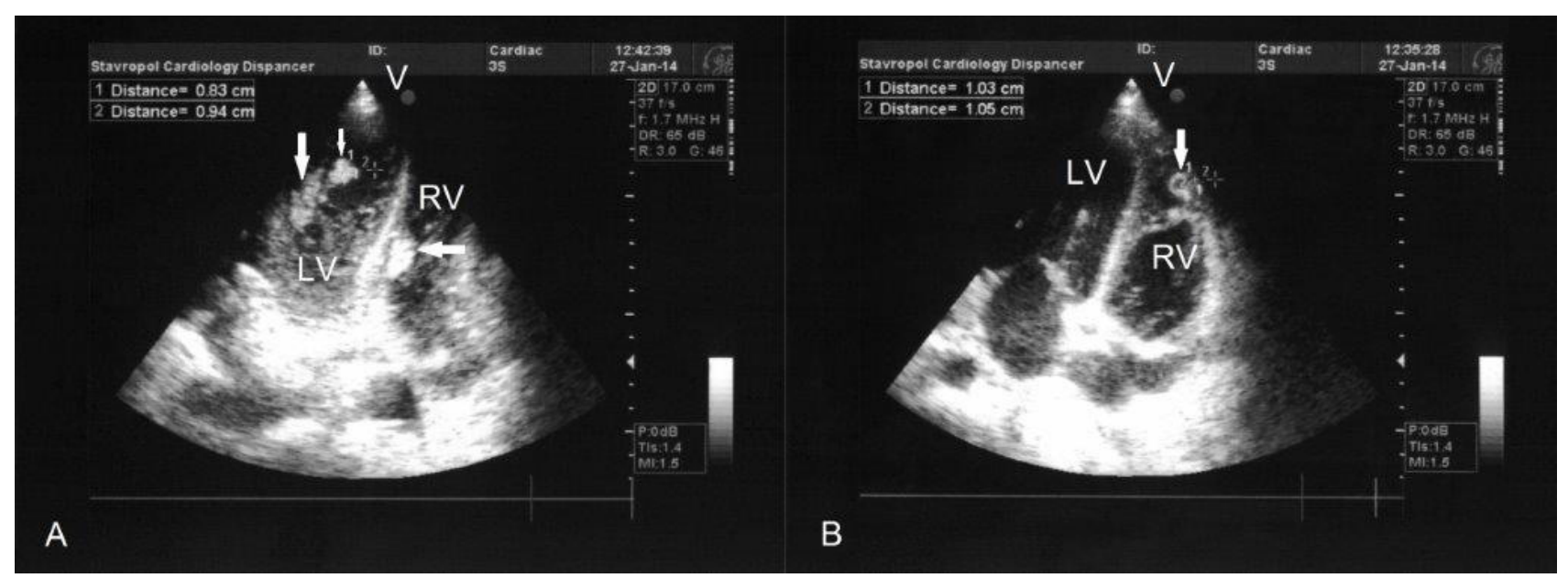

Fig. 1. Transthoracic echocardiogram on admission reveals multiple biventricular thrombi. (A) Big and small arrows represent mobile anterolateral apical thrombi of $\mathrm{LV}$, respectively $(0.8 \mathrm{~cm} \times 0.9 \mathrm{~cm} ; 1.5 \mathrm{~cm} \times 0.8 \mathrm{~cm})$. The horizontal arrow shows thrombus

in the middle portion of the septum of RV $(1.3 \mathrm{~cm} \times 1.0 \mathrm{~cm})$. (B) The arrow represents apical thrombus near the moderator band area of RV $(1.0 \times 1.0 \mathrm{~cm})$ with signs of lysis in the center. LV, Left ventricle; RV, Right ventricle

On the third day of admission echocardiography revealed increased volumes of ventricular and atrial cavities (left ventricular ejection fraction $37 \%$ ); the number of blood clots in the ventricles reduced to 3 , hypoecho- genic rarefactions appeared in their central parts, mobility of the thrombus in the apex area of the left ventricle increased with a thin stalk visualized (Fig. 2).

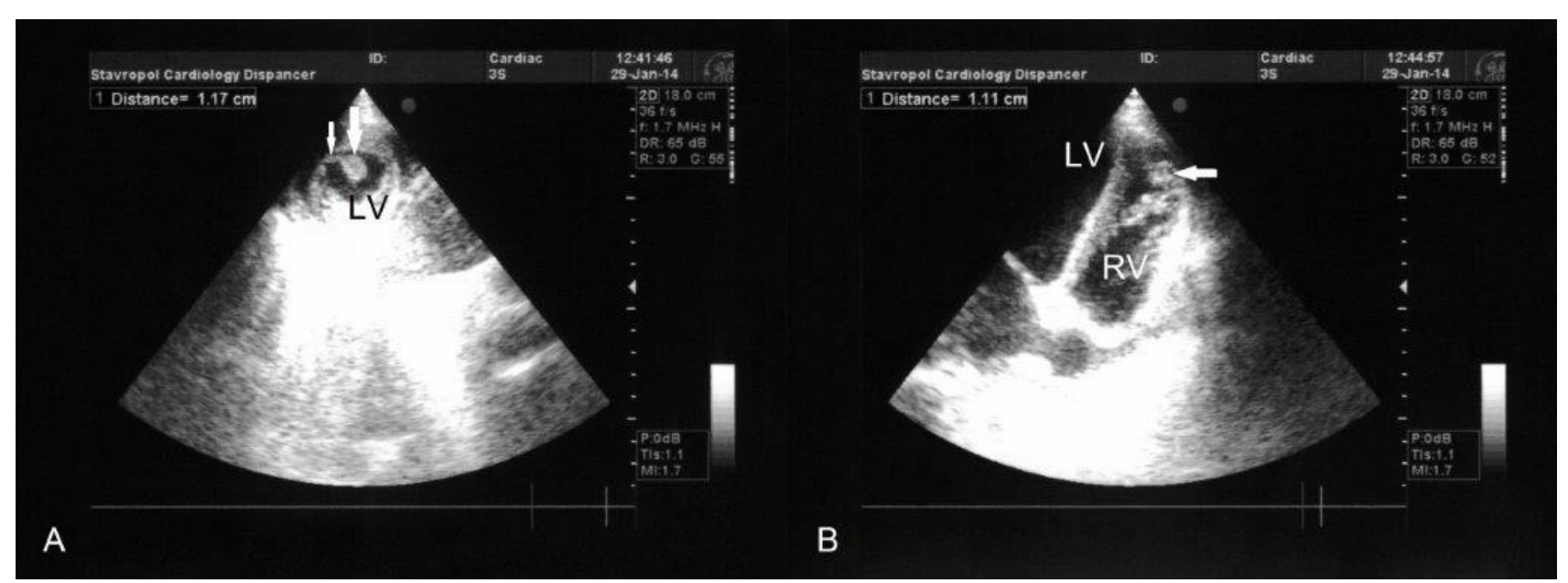

Fig. 2. Transthoracic echocardiogram on the 3rd day of admission: signs of increased mobility and further lysis of thrombi. (A) Apical LV thrombus (big arrow) floating on a stalk (small arrow) with a blood flow. (B) Decreased density of moderator band area thrombus. LV, Left ventricle; RV, Right ventricle 
On the tenth day of the admission, the dimensions of the cavities of the heart became closer to normal, left ventricular ejection fraction increased to $46 \%$, pulmonary hypertension resolved. Biventricular thrombi were not visualized and the patient was started on warfarin. Contrast-enhanced computed tomography (CT) scan of the thorax (in 2 weeks) showed areas of infarction in $\mathrm{S}_{6}$ and $\mathrm{S}_{9}$ of the right lung (Fig. 3 ).

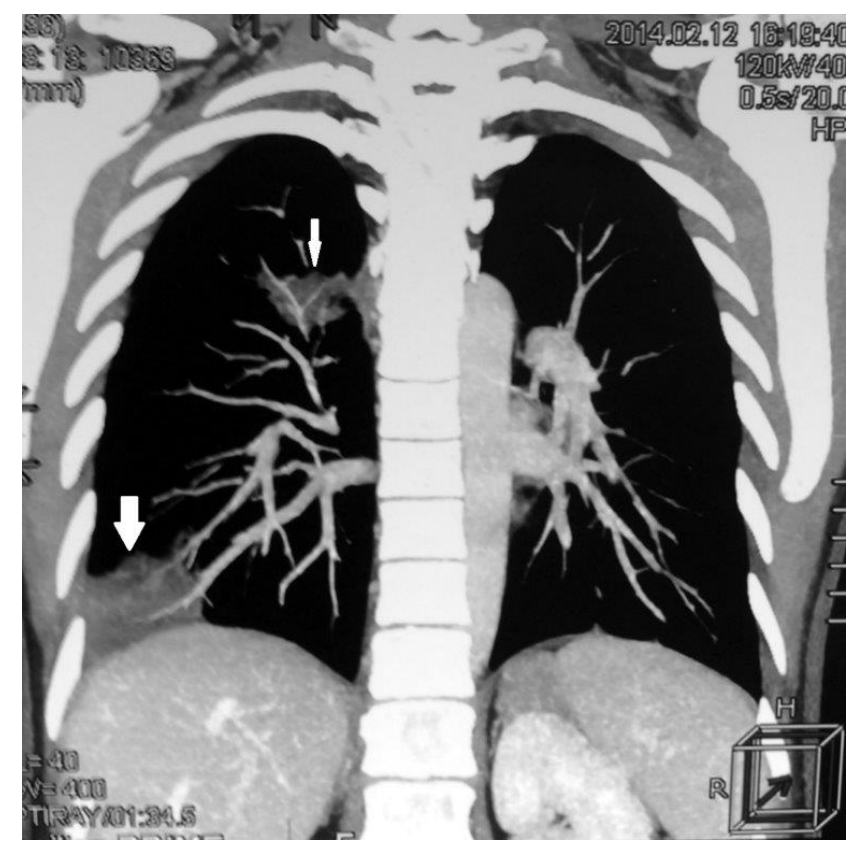

Fig. 3. Contrast-enhanced CT scan shows areas of right pulmonary infarction in $\mathrm{S}_{6}$ (small arrow) and $\mathrm{S}_{9}$ (big arrow) on the $2^{\text {nd }}$ week of admission

Genetic analysis of coagulation markers revealed fibrinolysis system gene polymorphisms: an antagonist of tissue activator of plasminogen type 1 (PA/1) 5G/4G in position -675 (heterozygote); defects in genes of platelet receptor glycoproteins: glycoprotein la (ITGA2) $807 \mathrm{C} / \mathrm{T}$ (heterozygote) and glycoprotein 3a (ITGB3) $1565 \mathrm{C} / \mathrm{C}$ (homozygote); 3 polymorphism of gene metabolism of folic acid and vitamin $\mathrm{B}_{12}$ : mutation 1298 $\mathrm{A} / \mathrm{C}$ (heterozygote) of one of methylenetetrahydrofolate reductase gene (MTHFR), the mutation $2756 \mathrm{~A} / \mathrm{G}$ (heterozygote) in a gene of $\mathrm{B}_{12}$-dependent methionine synthase (MTR) and mutation $66 \mathrm{G} / \mathrm{G}$ (homozygote) of methionine synthase reductase (MTRR) gene. There were no mutations of major coagulation genes found, such as: $1691 \mathrm{G} / \mathrm{G}$ of the factor $\mathrm{V}, 20210 \mathrm{G} / \mathrm{G}$ of the factor II, $10976 \mathrm{G} / \mathrm{G}$ of the factor VII, $-455 \mathrm{G} / \mathrm{G}$ of FGB-fibrinogen (factor I), G/G (Val34Leu) of the factor XIII.

Patient's clinical diagnosis included: familial peripartum cardiomyopathy with biventricular thrombi, pulmonary embolism with right necrotizing pneumonia $\left(\mathrm{S}_{6}, \mathrm{~S}_{9}\right)$, and congestive heart failure class IV (NYHA). Combined hereditary thrombophilia: heterozygous PAl1675 mutation of fibrinolysis system, homozygous ITGA2alpha2 mutation and heterozygous ITGB3-b mutation of a platelet component, folic acid and vitamin $B_{12}$ genes

References

1. Bultmann B. D., Klingel K., Nabauer M., Wallwiener D., Kandolf R. High prevalence of viral genomes and inflammation in peripartum cardiomyopathy. $A m$. J. Obstet Gynecol. 2005;193:363-365. doi: 10.1016/j. ajog.2005.01.022

2. Elkayam U., Akhter M. W., Singh H., Khan S., Bitar F. [et al.] Pregnancy-associated cardiomyopathy: clinical mutations: MTRR (homozygote), MTR and MTHFR-1298 (heterozygotes).

During 10-month follow-up the condition was satisfactory with no enlargement of heart cavities, and left ventricular ejection fraction of $65 \%$ (Teichholz) on echocardiography. Patient continued on warfarin.

Discussion. It is well-known that familial thrombophilia may be caused by mutations in encoding genes of coagulant and fibrinolytic systems of hemostasis, platelet receptor glycoproteins, and mutations in the genes that control the levels of homocysteine. Along with the common mutations/polymorphism of coagulation genes, i.e.: factor V (Leiden mutation), factors II, VII, I (FGB $\beta$-fibrinogen), factor XIII, resulting in the pathology of pregnancy, thrombophilia occurrence is often facilitated by the presence of «defective» gene alleles of fibrinolytic system [9].

Combined forms of hereditary thrombophilia, which occur in $5 \%$ of the population is considered as not only a major risk factor of thrombosis in general, but also as a common cause of complicated pregnancy - fetal loss and slow fetal growth, premature detachment of the placentae, gestational toxicosis, etc. At the same time, pregnancy and childbirth in and of itself serves as a provoking factor in thrombi formation. Being a potent coagulation activator, pregnancy triggers various coagulation components, which may turn into desynchronized response in the settings of defective allells controlling systems of aggregation, endothelial function and fibrinolysis, which may eventually cause a «coagulation burst».

In the observed case, a 28-year primigravida with hereditary thromboses and embolisms in female line developed a heart failure with significant decrease of contractile function, biventricular mobile thrombi, and right lung infarction (S6, S9) on the third day after the cesarean section. The underlying cause of this PPCM case is, we believe, a familial thrombophilia, which is based on a combination of genetic defects responsible for platelet receptors activity, fibrinolysis system and homocysteine metabolism.

In the settings platelet hyperadhesion, toxic effects on the endothelium and decreased fibrinolysis that are characteristic for thrombophilia, it is logical to assume causative role of coagulation impairments in rapid and significant reduction of myocardial function, which may become main therapeutic problem for the survivors. We believe that «exclusion» of a large volume of the distal coronary arteries from the circulation by microemboli can cause myocardial dysfunction in some cases of peripartum cardiomyopathy. Per our clinical observations, distal microemboli of the coronary vessels with the blockade of microcirculation and myocytes energy deficiency pays significant role in the development of systolic heart failure. In this regard, preventive anticoagulants treatment of PPCM patients in the presence of reduced LVEF is reasonable, even in the absence of obvious signs of thrombosis.

Conclusions. The presented clinical case, which resulted in the recovery of contractile function of the heart, characterizes the role of genetic factors of thrombophilia in the development of PPCM and its complications.

characteristics and a comparison between early and late presentation. Circulation. 2005;111:2050-2055. doi: 10.1161/01.CIR.0000162478.36652.7E

3. Goland S., Modi K., Bitar F., Janmohamed M. Mirocha J. M. [et al.] Clinical profile and predictors of complications in peripartum cardiomyopathy. J. Card. Fail. 2009;15:645-650. doi: 10.1016/j. cardfail.2009.03.008 
4. Lane D. A., Grant P. J. Role of hemostatic gene polymorphisms in venous and arterial thrombotic disease. Blood. 2000;95(5):1517-1532

5. Morales A., Painter T., Siegfried J. D., Li D., Norton N. [et al.] Rare variant mutations in pregnancyassociated or peripartum cardiomyopathy. Circulation. 2010;121:2176-2182. doi: 10.1161/ CIRCULATIONAHA.109.931220

6. Ntusi N. B., Mayosi B. M. Aetiology and risk factors of peripartum cardiomyopathy: a systematic review. Int. J. Cardiol. 2009;131:168-179. doi: 10.1016/j. ijcard.2008.06.054

7. Sakamoto A., Hosoya N., Kageyama S., Yoshizaki T., Takeuchi R. [et al.] Peripartum cardiomyopathy with biventricular thrombus which led to massive cerebral embolism. J. Cardiology Cases. 2014;9:71-74.
8. Sliwa K., Fett J., Elkayam U. Peripartum cardiomyopathy Lancet. 2006;368:687-693. doi: 10.1016/S01406736(06)69253-2

9. Torabi R., Zarei S., Zeraati H., Akhondi M. M., Hadavi R. [et al.] Combination of thrombophilic gene polymorphisms as a cause of increased the risk of recurrent pregnancy loss. J. Reproduct. Infertil. 2012;13:89-94.

10. Yagoda A., Gladkikh N., Gasparyan N., Koroy P., Septa I. A clinical case of recurrent peripartum cardiomyopathy complicated by intracardiac thrombosis. Medical News of North Caucasus. 2012;2(26):93-96.

11. Yamada N., Arinami T., Yamakawa-Kobayashi K., Watanabe H., Sohda S. [et al.] The 4G/5G polymorphism of the plasminogen activator inhibitor-1 gene is associated with severe preeclampsia. J. Hum. Genet. 2000;45:138-141. doi: 10.1007/s100380050

\title{
About authors:
}

Yagoda Alexander, MD, PhD, Professor Chair, Department of Hospital Therapy; tel.: +79064907330; email: alexander.yagoda@gmail.com Gladkikh Natalia, MD, PhD, Professor, Department of Hospital Therapy; tel.: +79682683497; e-mail: ngladkih@mail.ru

Znamenskaya Ilona, MD, Associate Professor; tel.: +79034190143; e-mail: znamia2011@yandex.ru

Dereva Madina, MD; tel.: +79887556008

Yagoda Sergey, MD; tel.: +79283212123; e-mail: sergey.yagoda@gmail.com

(c) Group of authors, 2017

UDC 616.36-002.895.8:615.1

DOI - https://doi.org/10.14300/mnnc.2017.12094

ISSN - 2073-8137

\section{OLANZAPINE IN TREATMENT OF A SCHIZOPHRENIC PATIENT WITH ORTHOTOPIC LIVER TRANSPLANT}

Bardenshtein L. M. ' , Enikeev I. ${ }^{2}$, Shcherbakova I. V. 1, Tsygankov B. D. ', Boev I. V. ${ }^{3}$, Aleshkina G. A. ${ }^{1}$

${ }^{1}$ Moscow State University of Medicine and Dentistry named after A. I. Evdokimov, Russian Federation

2 New York Psychiatric Services, USA

${ }^{3}$ Stavropol State Medical University, Russian Federation

\section{ПРИМЕНЕНИЕ ОААНЗАПИНА ПРИ АЕЧЕНИИ ШИЗОФРЕНИИ У ПАЦИЕНТА С ОРТОТОПИЧЕСКОЙ ТРАНСПААНТАЦИЕЙ ПЕЧЕНИ}

\author{
А. М. Барденштейн ${ }^{1}$, И. Еникеев ${ }^{2}$, И. В. Щербакова ', Б. А. Цыганков ${ }^{\text {, }}$ \\ И. В. Боев ${ }^{3}$, Г. А. А^ешкина ${ }^{1}$
}

\author{
${ }^{1}$ Московский госУАарственный МеАико-стоматологический Университет \\ им. А. И. ЕвАоКИмова, РосСиЙская ФеАерация \\ 2 Центр психиатрической помощи, Нью-Иорк, США \\ ${ }^{3}$ Ставропольский госуАарственный МеАицинский университет, Российская ФеАерация
}

Presents a clinical case of a patient with paranoid schizophrenia and orthotopic transplant of the liver (02.12.2011) Constantly takes immunosupressivny therapy: tacrolimus, mycophenolate mofetil. Start of mental illness is, in all probability, to 2011, when first appeared the verbal deceptions of perception and ideas of its specific mission and significance. In July 2014 the patient's mental state significantly deteriorated: he developed hallucinatory-paranoid state, katotonia-oneiric inclusions, and he was hospitalized in a psychiatric hospital. The main difficulty encountered in the management of this patient, was the choice of antipsychotic drug. As the pathogenetic treatment of schizophrenia, we used atypical antipsychotic olanzapine. The choice of this drug was due to the high clinical efficacy of olanzapine in the treatment of disease and a low risk of unwanted side effects - hepatotoxicity, extrapyramidal symptoms. It makes olanzapine the most preferred for the treatment of schizophrenia in a patient with hepatitis $\mathrm{C}$ and liver transplant.

Keywords: paranoid schizophrenia, chronic hepatitis C, liver transplantation, comorbidity, antipsychotic drugs, olanzapine 